\title{
A NEW MODEL TO IMPROVE SERVICE QUALITY IN THE PROPERTY MANAGEMENT INDUSTRY
}

\author{
Ting-Yi CHIANG ${ }^{1, *}$, Yeng-Horng PERNG ${ }^{1}$ \\ ${ }^{1}$ Department of Architecture, National Taiwan University of Science and Technology, No.43, Sec. 4, Keelung Rd., \\ Da-an Dist., Taipei City 10 607, Taiwan
}

Received 25 December 2017; accepted 28 June 2018

\begin{abstract}
The categories and quality attributes of property services valued by customers in Taiwan are discussed in this paper. We proposed a hybrid model that combines SERVQUAL, the Kano model, and the Refined Kano model in order to examine a sample of three hundred customers. The results show that the new model analysis validated the effectiveness of the proposed approach while maintaining classification power at par with the Kano questionnaire; a lower turnover rate of service staff (X14) shall be considered the quality attribute of Potential (P), inferring that a lower dismissal rate of service staff allows the management to reduce oft-incurred training expenditures and maintain the company's competitiveness. Indeed, a more consumer-oriented point of view and differentiated service strategies may effectively resolve the cognitive gap (and eventually the overall gap) between property service staff and customers. Consequently, property services providers would do well either to collaborate with research institutions or to carry out periodic surveys using questionnaires to improve the quality of their services.
\end{abstract}

Keywords: property services, service research, SERVQUAL, Kano model, Refined Kano model.

\section{Introduction}

As our society modernizes, the demand for higher residential living quality and services rises along with it. The management of residential communities must be entrusted to professionals and efficient property services operators who are capable of providing comprehensive and professional quality services. Given that service quality is the key prefactor (Anderson \& Mittal, 2000; Hurley \& Estelami, 1998; Wang, Kim, Ko, \& Liu, 2016) leading to better customer satisfaction, only by reinforcing it may the caliber of the property service sector in Taiwan be increased, eventually pulling up efficiency and profitability with it (Anderson \& Mittal, 2000; Ooi, Lin, Tan, \& Chong, 2011; Parasuraman, Zeithaml, \& Berry, 1985; Tontini, Søilen, \& Silveira, 2013). SERVQUAL was the service quality assessment method set forth by Parasuraman, Zeithaml, and Berry (1988) to measure customer satisfaction in 1988. Results of many studies reveal that customers tend to have different perceptions regarding service quality (F. A. Ferreira, Spahr, Sunderman, Banaitis, \& J. J. Ferreira, 2017; Nadiri \& Hussain, 2005; Wang \& Ji, 2010; Wang, Luor, Luarn, \& Lu, 2015). Based on the aforementioned rationale, this study uses SERVQUAL and the Kano two-dimensional model (hereafter, the Kano model) as means for classification (Kano, Seraku, Takahashi, \& Tsuji, 1984). Then, by combining the Refined Kano model into the mix, a tool which takes into account the importance of all categorized qualities, higher accuracy can be attained (Yang, 2005). This study aims to find out the needs of customers as well as evaluate the performance of property services providers, by using a hybrid model as a measure of service quality in the property management industry. By means of the analysis, the model can be used to improve the strategy of differentiation for the property services industry and can also the help CEOs and managers to plan programs bearing in mind customers' needs. There is an essential need to find an effective way to translate customer requirements into a set of service quality elements formed according to their perspective. The remainder of this paper is structured as follows. First, a problem statement and literature review are presented, followed by a section outlining the methodology, research design, data collection, and discussion. Subsequently, we derive the results of the discussion and present our conclusion and recommendations.

*Corresponding author. E-mails: D10313014@mail.ntust.edu.tw, lv198012@gmail.com 


\section{Problem statement}

Although the property management industry developed early in Taiwan, the regulations and market mechanisms have been far from adequate, making Taiwan fall far behind other countries. Due to low entry barriers into the property management sector, the influx of service providers from different industries led to chaos and competition. Moreover, the excessive number of small- and mediumsized enterprises in this industry often led competitors to engage in price wars, resulting in service quality disparity, and the ensuing vicious circle has made the conduct of business operations increasingly difficult. The scope of a property services provider's work often includes providing security guards, janitorial and maintenance services, doing basic accounting tasks, and other relevant tasks to improve the residential environment and community's development (Griswold, 2013; Hopkins, Read, \& Goss, 2017; Read, Goss, \& Hopkins, 2017). This gap in the extant literature is noteworthy because these kinds of firms manage millions of apartment units across the country, and the number continues to grow. For this reason, most clients have become disillusioned with property services. Nonetheless, though many researchers have conducted many studies on specific service sectors, very few have been dedicated to property services. Therefore, given that property service management is still a relatively new topic in Taiwan that requires more in-depth study, the goal of the present research is to analyze the aforementioned demand, along with current market conditions and issues, so that we may to identify possible solutions. Also, this study aims at probing across the needs of customers as well as the performance of property services providers.

\section{Literature review}

\subsection{Service quality}

Service quality supports customer satisfaction while motivating recommendations and promoting the intention to return (Ferreira et al., 2017; Nadiri \& Hussain, 2005). It is a key predictor of the future success of businesses that thrive on having a service orientation. Thus, it indicates the gap between consumers' initial service expectations and the actual service they receive (Oh \& Kim, 2017; Parasuraman et al., 1985). Parasuraman et al. (1998) developed SERVQUAL as an instrument to measure service quality. It is the most commonly used approach for measuring service quality, which compares customers' expectations before their service encounter with their perceptions regarding the actual service after their service encounter (Parasuraman et al., 1985; Wang et al., 2015). SERVQUAL has five generic dimensions or factors (Van Iwaarden, van der Wiele, Ball, \& Millen, 2003; Wang et al., 2015):

- Tangibles: Physical facilities, equipment, and appearance of personnel.

- Reliability: Ability to perform the promised service dependably and accurately.
- Responsiveness: Willingness to help customers and provide prompt service.

- Assurance: Stemming from competence, courtesy, credibility, and security; knowledgeableness and the courtesy extended by employees and their corresponding ability to inspire trust and confidence.

- Empathy: Derived from access, communication, and understanding the customer, this attribute comes from caring and individualized attention that a firm provides to its customers.

As SERVQUAL instruments capture service quality in multiple dimensions, this study utilized those aspects developed by Parasuraman et al. (1998). The literature reveals that few studies on quality measurement scales for property service have been conducted, presumably because using property services was not especially popular during the 1990s. Since then, the business environment for property service has been in constant flux. Therefore, quality measurement scales for property services should be updated to reflect the new environment. Nowadays, property services have become important revenue generators, but the literature lacks quality measurement scales that are suitable for property service provision. Related literature on property management largely adopts the field operations perspective in analyzing performance indicators, service quality, and customer satisfaction, without exactly targeting residential property management services. With respect to assessment scales, most studies designed their own measurements, which were not based on related fundamental theories (W. T. Chen, Huang, \& J. W. Chen, 2016).

\subsection{Kano's model}

Since Kano et al. (1984) proposition of the two-dimensional quality model, it has been widely accepted and applied. The two-dimensional quality model (Kano et al., 1984) was developed by adapting the motivation-hygiene theory of Herzberg, Mausner, and Snyderman (1959). Kano et al. (1984) applied two dimensions of any quality attribute: quality fulfillment and customer-perceived satisfaction. The Kano model classifies service quality attributes into the following: Attractive (A), Must be (M), One-Dimensional $(\mathrm{O})$, Indifferent $(\mathrm{I})$, and Reverse $(\mathrm{R})$ (Kano et al., 1984; Luor, Lu, Chien, \& Wu, 2015; Matzler \& Hinterhuber, 1998; Witell, Löfgren, \& Dahlgaard, 2013). The list below provides more details:

- Attractive (A): Attractive quality attributes can be described as surprising and delightful attributes, which provide satisfaction when fully achieved but do not cause dissatisfaction when they are not.

- Must be (M): These requirements form the basic criteria for a good product or the basic needs/expectations of the potential customers/users. They are the basic features customers/users expect from a software. They are the threshold requirements. Thus, must-be quality attributes are taken for granted when fulfilled but result in dissatisfaction when they are not. 
- One-Dimensional (O): This is a no-preference requirement, which implies that the user/customer is indifferent to the requirement/feature. He does not care if the feature is present. Users simply do not care about it. It is neither good nor bad, and its presence does not result in either satisfaction or dissatisfaction for users/customers.

- Indifferent (I): Customer satisfaction will be unaffected whether or not this quality is provided.

- Reverse (R): This is an inverse requirement (i.e., it could run either way); the user/customer's expectations about the feature are in reverse order. Thus, customers will be dissatisfied if such quality attributes are provided; otherwise, they will be satisfied.

Many previous studies have applied the Kano model to measure customer satisfaction. Related research includes that done on hotel industry (Dominici \& Palumbo, 2013; Yang, Jou, \& Cheng, 2011), the food and beverage industry (Chen, 2012), airlines (Basfirinci \& Mitra, 2015; Hu \& Hsiao, 2016), and product and service design (Borgianni \& Rotini, 2015; Kim \& Choi, 2017). However, most of this research addresses service business, and little research is focused on service quality in the property management industry. The Kano model has some shortcomings. It places little emphasis on decision-making methods for service quality improvement. It also fails to account for the provider's concerns in terms of the capacity to fulfill customer requirements (Mikulić \& Prebežac, 2011; Shahin, Pourhamidi, Antony, \& Hyun Park, 2013). Research that challenges the Kano methodology of the theory of attractive quality is scarce (Luor et al., 2015; Witell et al., 2013). This research used the SERVQUAL, Kano model, and the Refined Kano model to explore property services, with a view to assist enterprises in improving customer satisfaction, which will be wise than the use of a single identification model.

\section{Research design and data collection}

\subsection{Questionnaire design and preparation}

The questionnaire was generated by gathering existing documentation and investigation with respect to the service criteria provided by different property service operators (e.g., Chen et al., 2016; Dabholkar, Thorpe, \& Rentz, 1996; Das, Kumar, \& Saha, 2010; Griswold, 2013; Lu, Shiu, \& Chang, 2014; Zhao, Bai, \& Hui, 2002). A questionnaire was designed after summarizing the related literature, followed by an expert in-depth interview, which aimed to gain insight into the themes of respondents, suggesting that depth is more important than width (H. J. Rubin \& I. S. Rubin, 2011). Sometimes, certain respondents' personal observation might be sufficient in representing hundreds of people's experiences (Chiang, Perng, \& Liou, 2017; Weiss, 1994). Moreover, the fundamental structure of the questionnaire, based on SERVQUAL and enhanced by Parasuraman et al. (1988), was designed specifically to analyze the cognitive gap between consumers and property services providers. During this process, managers and professional researchers who specialized in property service management were invited to conduct interviews that helped them revise, compile, and perfect the service criterion proposed in the questionnaire. As a result, we have defined a total of forty service items (Table 1).

Table 1. List of property service items

Property innovation and value creating service quality items

\section{Reputation}

2. Prevention of violations in public areas

3. Proper management of public funds

4. Proper handover of public facilities

5. Friendly service staff and secure vehicle parking

6. Sound management of agent and house viewing

7. Premium administration

8. Protection of residents' privacy

9. Proper financial management

10. Good two-way communication

11. Establishment of livable environment

12. Craftsman services

13. Attire and demeanor of service staff

14. Service staff's capacity to cater different needs of clients

15. E-community

16. Active community and club activities

17. A lower turnover rate of service staff

18. Community service personnel can actively propose solutions and get emergency responses

19. Community education

20. Proper storage of community assets
21. Community exchange

22. Proactive landscaping

23. Customized services

24. Maintenance of the exterior of the building, garden landscape, and public space

25. Maintenance of buildings'service life

26. Employees are welcoming and friendly

27. Service staff respond sprom ptand adequately to queries

28. Positive media report

29. Increase in community position

30. Right attitudes and professional practices

31. Service staff takes corrective action immediately in case of mistakes

32. Energy conservation and carbon reduction

33. Proper maintenance of decor and construction

34. Proper communication and consensus gathering on bulletin and community publications

35. Proactive and promptness in taking corrective actions when faults occur

36. Refined property management

37. Active problem solving

38. Award-winning premium community

39. Hotel-based service

40. Strict access control 


\section{Preliminary survey and response}

In order to prioritize the service qualities attributes, the preliminary questionnaire adopted a five-point scoring scale ranging from 1 (very unimportant) to 5 (very important). The sample selected consists of 50 people who are managers from property services firms, heads of community management committees, and residents. The questionnaire was then revised and finalized after the preliminary surveyed was completed. A total of 50 questionnaires were issued for the preliminary survey, with 48 questionnaires filled out and returned ( $96 \%$ response rate). We then removed the invalid questionnaires, and collected a total of 46 valid questionnaires we with a $95.83 \%$ response rate.

\section{Reliability and validity analysis}

Following the reliability analysis, 8 questions with lower coefficient (Cronbach's $\alpha$ ) below 0.35 were eliminated, while 32 questions were retained. The result of the analysis shows that the questionnaire had an overall coefficient for Cronbach's $\alpha$ of 0.955 , implying a high reliability (Nunnally, 1978). Exploratory factor analysis was conducted, and principal component analysis was employed in combination with orthogonal rotation to consolidate the questions, thus eliminating several nondiscriminatory questions by following the methods proposed by Hair, Black, Babin, Anderson, and Tatham (2009). Calculation of factor loads using the principal components method is straightforward; the original components do not change if the number of factors (components) increases. The simplicity of this method means that it is among the most commonly used (Dočekalová \& Kocmanová, 2016; Watson, 2017). Principal component analysis was employed to analyze 32 parameters. The correlation matrix of variables was generated, and the factors were extracted using the centroid method before being rotated using varimax rotation. The five factor variates were extracted through factor analysis, with a total cumulative variance of $89.32 \%$ and a Kaiser-Meyer-Olkin score of 0.83 . The approximate chi squared value obtained according to Bartlett's test of sphericity was 2693.65 (d.f. = 496), and the factor analysis results suggested that the first five eigenvalues were significant (i.e., greater than 1). A scree plot of the factor analysis is illustrated in Figure 1.

Table 2 indicates that the first five components explained $89.32 \%$ of the total variance, whereas the remain-

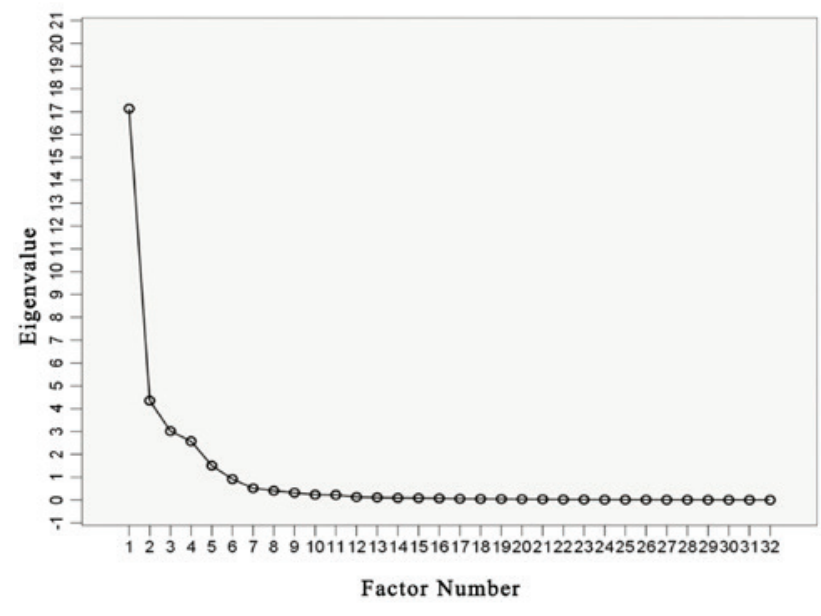

Figure 1. Scree plot of the eigenvalues

der of the components explained only $10.68 \%$ of total variance in the data set. This survey method was validated by Liu, Lin, and Kuo (2003), who classified the factor loadings as "strong," "moderate," and "weak," corresponding to absolute loading values of $>0.75,0.75-0.50$, and $0.50-0.30$, respectively. This indicated that the study's questionnaire was highly valued by respondents.

Table 2 lists the total variance explained by the first five factors for both the rotated and unrotated factor loadings, from which the property service items were categorized into the following facets: tangibles, reliability, responsiveness, assurance, and empathy (Table 3).

\subsection{Current status survey}

We carried out a survey of residents currently living in New Taipei City using the judgmental sampling method. Judgmental sampling is referred to as purposeful sample since the researcher selects the most productive sample to answer the research question (Marshall, 1996; D. Mishra, Akman, \& A. Mishra, 2014). We have selected the sample from medium to small sized residential communities with less than two hundred households. Visits and interviews were carried out with residents, community managers, of property services providers to better understand the delivery of property services within their communities, followed by dialogs with chairpersons of residential community management committees. This study proposed a hypothesis. To thoroughly understand the situation of

Table 2. Extracted values of the principal component analysis parameters

\begin{tabular}{|c|c|c|c|c|c|c|}
\hline \multirow{2}{*}{ Component } & \multicolumn{3}{|c|}{ Extraction sum of squared loadings } & \multicolumn{3}{c|}{ Rotation sum of squared loadings } \\
\cline { 2 - 7 } & Total & \% of variance & Cumulative \% & Total & \% of variance & Cumulative \% \\
\hline 1 & 17.14 & 53.56 & 53.56 & 6.77 & 21.16 & 21.16 \\
\hline 2 & 4.35 & 13.59 & 67.15 & 6.18 & 19.31 & 40.48 \\
\hline 3 & 3.01 & 9.42 & 76.58 & 5.91 & 18.48 & 58.96 \\
\hline 4 & 2.57 & 8.03 & 84.61 & 5.26 & 16.46 & 75.42 \\
\hline 5 & 1.50 & 4.70 & 89.32 & 4.44 & 13.90 & 89.32 \\
\hline
\end{tabular}


Table 3. List of SERVQUAL facets of measurement and questions

\begin{tabular}{|c|c|c|}
\hline Items & $\begin{array}{c}\text { SERVQUAL } \\
\text { dimension }\end{array}$ & Property innovation and value creating service quality items \\
\hline 1 & Tangibles & $\begin{array}{l}\text { X1. Establishment of livable environment } \\
\text { X2. E-community } \\
\text { X3. Proactive landscaping } \\
\text { X4. Increase in community position } \\
\text { X5. Energy conservation and carbon reduction } \\
\text { X6. Award-winning premium community }\end{array}$ \\
\hline 2 & Reliability & $\begin{array}{l}\text { X7. Reputation } \\
\text { X8. Premium administration } \\
\text { X9. Good two-way communication } \\
\text { X10. Craftsman services } \\
\text { X11. Positive media report } \\
\text { X12. Right attitudes and professional practices } \\
\text { X13. Hotel-based service } \\
\text { X14. A lower turnover rate of service staff }\end{array}$ \\
\hline 3 & Responsiveness & $\begin{array}{l}\text { X15. Prevention of violations in public areas } \\
\text { X16. Sound management of agent and house viewing } \\
\text { X17. Community education } \\
\text { X18. Community exchange } \\
\text { X19. Proper communication and consensus gathering on bulletin and community publications } \\
\text { X20. Refined property management }\end{array}$ \\
\hline 4 & Assurance & $\begin{array}{l}\text { X21. Proper management of public funds } \\
\text { X22. Proper handover of public facilities } \\
\text { X23. Proper financial management } \\
\text { X24. Proper storage of community assets } \\
\text { X25. Maintenance of buildings' service life } \\
\text { X26. Strict access control }\end{array}$ \\
\hline 5 & Empathy & $\begin{array}{l}\text { X27. Protection of residents' privacy } \\
\text { X28. Customized services } \\
\text { X29. Proper maintenance of decor and construction } \\
\text { X30. Active problem solving } \\
\text { X31. Active community and club activities } \\
\text { X32. Community service personnel can actively propose solutions and get emergency responses }\end{array}$ \\
\hline
\end{tabular}

property management service quality, base on Kano model it should be classified into different quality attribute. We corrected problems such as equivocal wording, syntax errors, overuse of jargon, insufficient for finishing the questionnaire, and any biased factors in the scale (Park, El Sawy, \& Fiss, 2017; H. J. Rubin \& I. S. Rubin, 2011). Regarding the limitation of study, there are indeed very few number of residential communities in Taiwan who are qualified for the survey. The fact that most interviewees belong to middle to upper social classes made it more difficult to collect responses, and it took over one year to collect all the questionnaires.

\section{Sample structure analysis}

Totally, 300 questionnaires were issued with 259 copies filled out and responded, with a response rate at $86.33 \%$. However, we removed the invalid questionnaires (uncompleted, biased response, and with reverse quality elements: R), and collected a total of 228 valid questionnaires, with valid rate at $88.03 \%$, which is very good in academic studies (Baruch \& Holtom, 2008). The reliability summary concludes that Cronbach's $\alpha$ value of presence-positive is at 0.922 ; absence-negative at 0.941 ; coefficient of importance is 0.831 , indicating that all fac- ets are highly reliable $(\alpha>0.7)$. A Cronbach's $\alpha$ value between 0.70 and 0.95 indicates good internal consistency (Terwee et al., 2007).

\section{Kano operation result analysis}

\subsection{Classification of Kano quality attributes}

Kano Quality Attributes (Table 4) showed that customers have visibly divergent perceptions toward property services qualities. The reason why the Reverse quality attributes ( $R$ ) have been absent in this study is that when $R$ exists, on the one hand, customers tended to be dissatisfied. On the other hand, when $\mathrm{R}$ was absent, customers appeared to have more positive opinions about the services provided. Moreover, many studies and documents have not taken the Reverse quality attributes $(R)$ of the Kano model into account. Further to the result of the analysis, 7 items of "X8, X9, X12, X15, X19, X29, X30" fall into class $\mathrm{M}, 10$ items "X1, X2, X7, X10, X13, X20, $\mathrm{X} 21, \mathrm{X} 23, \mathrm{X} 25, \mathrm{X} 26$ " fall into O, and 6 items of "X3, X4, $\mathrm{X} 24, \mathrm{X} 27, \mathrm{X} 28, \mathrm{X} 32$ " fall into A, with 9 items of "X5, X6, $\mathrm{X} 11, \mathrm{X} 14, \mathrm{X} 16, \mathrm{X} 17, \mathrm{X} 18, \mathrm{X} 22, \mathrm{X} 31$ ” fall into I at last, hence 32 items in total. 
Table 4. Kano quality attributes

\begin{tabular}{|c|c|c|c|c|c|c|c|c|c|c|}
\hline Dimension & Items & $\mathrm{A}$ & $\mathrm{O}$ & M & I & Category & SC & Sequence & DSC & Sequence \\
\hline \multirow{6}{*}{$\begin{array}{l}\frac{\ddot{O}}{0} \\
\overrightarrow{00} \\
\stackrel{\Xi}{=}\end{array}$} & $\mathrm{X} 1$ & 19.30 & 27.63 & 27.63 & 25.44 & $\mathrm{O}$ & 46.93 & 21 & -55.26 & 27 \\
\hline & $\mathrm{X} 2$ & 25.44 & 29.39 & 23.25 & 21.93 & $\mathrm{O}$ & 54.82 & 8 & -52.63 & 20 \\
\hline & X3 & 26.32 & 25.00 & 25.44 & 23.25 & $\mathrm{~A}$ & 51.32 & 13 & -50.44 & 10 \\
\hline & $\mathrm{X} 4$ & 27.19 & 25.88 & 24.56 & 22.37 & $\mathrm{~A}$ & 53.07 & 12 & -50.44 & 10 \\
\hline & $\mathrm{X} 5$ & 19.30 & 24.12 & 28.07 & 28.51 & I & 43.42 & 30 & -52.19 & 18 \\
\hline & X6 & 19.74 & 25.88 & 24.56 & 29.82 & I & 45.61 & 25 & -50.44 & 10 \\
\hline Average & & & & & & & 49.20 & & -51.90 & \\
\hline \multirow{8}{*}{ 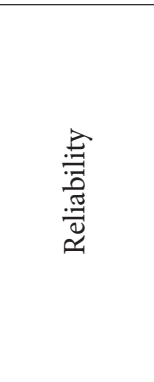 } & $\mathrm{X} 7$ & 25.88 & 27.63 & 25.44 & 21.05 & $\mathrm{O}$ & 53.51 & 10 & -53.07 & 23 \\
\hline & $\mathrm{X} 8$ & 20.61 & 24.56 & 28.07 & 26.75 & $\mathrm{M}$ & 45.18 & 27 & -52.63 & 20 \\
\hline & X9 & 22.37 & 26.32 & 29.39 & 21.93 & $\mathrm{M}$ & 48.68 & 18 & -55.70 & 28 \\
\hline & $\mathrm{X} 10$ & 25.00 & 28.51 & 23.68 & 22.81 & $\mathrm{O}$ & 53.51 & 10 & -52.19 & 18 \\
\hline & $\mathrm{X} 11$ & 21.49 & 20.61 & 28.07 & 29.82 & $\mathrm{I}$ & 42.11 & 31 & -48.68 & 5 \\
\hline & $\mathrm{X} 12$ & 22.37 & 26.75 & 28.07 & 22.81 & $\mathrm{M}$ & 49.12 & 16 & -54.82 & 26 \\
\hline & $\mathrm{X} 13$ & 26.75 & 28.95 & 18.86 & 25.44 & $\mathrm{O}$ & 55.70 & 5 & -47.81 & 1 \\
\hline & $\mathrm{X} 14$ & 17.98 & 27.63 & 25.00 & 29.39 & I & 45.61 & 25 & -52.63 & 20 \\
\hline Average & & & & & & & 49.18 & & -52.19 & \\
\hline \multirow{6}{*}{ 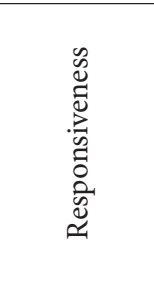 } & $\mathrm{X} 15$ & 23.68 & 26.75 & 29.39 & 20.18 & $\mathrm{M}$ & 50.44 & 15 & -56.14 & 30 \\
\hline & $\mathrm{X} 16$ & 22.81 & 23.25 & 26.75 & 27.19 & $\mathrm{I}$ & 46.05 & 23 & -50.00 & 9 \\
\hline & $\mathrm{X} 17$ & 24.56 & 21.49 & 26.75 & 27.19 & I & 46.05 & 23 & -48.25 & 3 \\
\hline & $\mathrm{X} 18$ & 21.49 & 23.68 & 27.19 & 27.63 & I & 45.18 & 27 & -50.88 & 13 \\
\hline & X19 & 23.68 & 21.49 & 29.39 & 25.44 & $\mathrm{M}$ & 45.18 & 27 & -50.88 & 13 \\
\hline & $\mathrm{X} 20$ & 27.63 & 29.82 & 18.86 & 23.68 & $\mathrm{O}$ & 57.46 & 2 & -48.68 & 5 \\
\hline Average & & & & & & & 48.39 & & -50.80 & \\
\hline \multirow{6}{*}{ 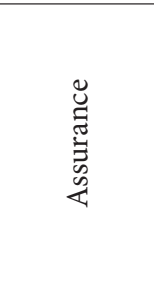 } & $\mathrm{X} 21$ & 26.32 & 28.95 & 22.37 & 22.37 & $\mathrm{O}$ & 55.26 & 6 & -51.32 & 16 \\
\hline & X22 & 23.68 & 22.81 & 26.32 & 27.19 & I & 46.49 & 22 & -49.12 & 8 \\
\hline & $\mathrm{X} 23$ & 26.32 & 29.82 & 27.19 & 16.67 & $\mathrm{O}$ & 56.14 & 4 & -57.02 & 31 \\
\hline & $\mathrm{X} 24$ & 28.51 & 26.75 & 24.12 & 20.61 & $\mathrm{~A}$ & 55.26 & 6 & -50.88 & 13 \\
\hline & $\mathrm{X} 25$ & 25.88 & 32.89 & 22.81 & 18.42 & $\mathrm{O}$ & 58.77 & 1 & -55.70 & 28 \\
\hline & $\mathrm{X} 26$ & 25.88 & 31.58 & 21.93 & 20.61 & $\mathrm{O}$ & 57.46 & 2 & -53.51 & 24 \\
\hline Average & & & & & & & 54.90 & & -52.92 & \\
\hline \multirow{6}{*}{ 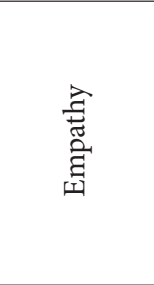 } & $\mathrm{X} 27$ & 27.19 & 26.75 & 25.00 & 21.05 & $\mathrm{~A}$ & 53.95 & 9 & -51.75 & 17 \\
\hline & $\mathrm{X} 28$ & 27.63 & 23.68 & 25.00 & 23.68 & $\mathrm{~A}$ & 51.32 & 13 & -48.68 & 5 \\
\hline & X29 & 22.37 & 25.88 & 27.63 & 24.12 & $\mathrm{M}$ & 48.25 & 19 & -53.51 & 24 \\
\hline & $\mathrm{X} 30$ & 19.30 & 28.07 & 29.39 & 23.25 & $\mathrm{M}$ & 47.37 & 20 & -57.46 & 32 \\
\hline & X31 & 21.93 & 19.74 & 28.51 & 29.82 & $\mathrm{I}$ & 41.67 & 32 & -48.25 & 3 \\
\hline & $\mathrm{X} 32$ & 27.19 & 21.93 & 25.88 & 25.00 & $\mathrm{~A}$ & 49.12 & 16 & -47.81 & 1 \\
\hline Average & & & & & & & 48.61 & & -51.24 & \\
\hline
\end{tabular}

\subsection{Analysis of quality improvement satisfaction index}

The study undertaken by Matzler and Hinterhuber (1988), revised the classification of Kano quality attributes. The following customer satisfaction index illustrated in formulae $1 \& 2$ was instead suggested:

Extent of satisfaction $(\mathrm{SC})=(\mathrm{A}+\mathrm{O}) /(\mathrm{A}+\mathrm{O}+\mathrm{M}+\mathrm{I}) ;(1)$

Extent of dissatisfaction coefficient $(\mathrm{DSC})=-(\mathrm{O}+\mathrm{M}) /$ $(\mathrm{A}+\mathrm{O}+\mathrm{M}+\mathrm{I})$.
Among the five facets, Assurance had the highest importance with SC at $54.90 \%$ and DSC at $-52.92 \%$, followed by Responsiveness, Empathy, Tangibles, Reliability, etc. Hence, if the service provider would be able to bring up the Assurance facet, the overall quality of property services would also be upgraded (Table 4 ).

\subsection{Refined Kano classification based on refined Kano quality attributes}

The Refined Kano model was derived from the Kano model by adding the degree of importance, with the goal 
Table 5. Refined Kano quality attributes

\begin{tabular}{|c|c|c|c|c|c|c|c|}
\hline Dimension & Items & $\mathrm{A}$ & $\mathrm{O}$ & $\mathrm{M}$ & I & Importance & Category \\
\hline \multirow{6}{*}{ 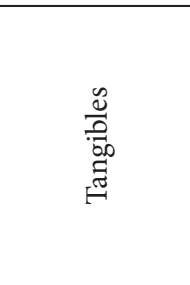 } & $\mathrm{X} 1$ & 19.30 & 27.63 & 27.63 & 25.44 & 3.99 & $\mathrm{HV}$ \\
\hline & $\mathrm{X} 2$ & 25.44 & 29.39 & 23.25 & 21.93 & 3.70 & $\mathrm{HV}$ \\
\hline & $\mathrm{X} 3$ & 26.32 & 25.00 & 25.44 & 23.25 & 3.78 & HA \\
\hline & $\mathrm{X} 4$ & 27.19 & 25.88 & 24.56 & 22.37 & 3.48 & LA \\
\hline & $\mathrm{X} 5$ & 19.30 & 24.12 & 28.07 & 28.51 & 3.54 & $\mathrm{CF}$ \\
\hline & $\mathrm{X} 6$ & 19.74 & 25.88 & 24.56 & 29.82 & 3.46 & $\mathrm{CF}$ \\
\hline Average & & & & & & 3.66 & \\
\hline \multirow{8}{*}{ 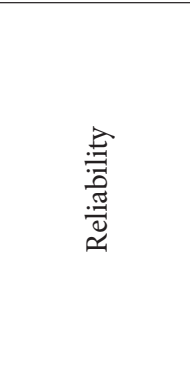 } & $\mathrm{X7}$ & 25.88 & 27.63 & 25.44 & 21.05 & 3.72 & $\mathrm{HV}$ \\
\hline & $\mathrm{X} 8$ & 20.61 & 24.56 & 28.07 & 26.75 & 3.30 & $\mathrm{~N}$ \\
\hline & X9 & 22.37 & 26.32 & 29.39 & 21.93 & 3.94 & $\mathrm{C}$ \\
\hline & $\mathrm{X} 10$ & 25.00 & 28.51 & 23.68 & 22.81 & 3.70 & $\mathrm{HV}$ \\
\hline & $\mathrm{X} 11$ & 21.49 & 20.61 & 28.07 & 29.82 & 3.38 & CF \\
\hline & $\mathrm{X} 12$ & 22.37 & 26.75 & 28.07 & 22.81 & 3.97 & $\mathrm{C}$ \\
\hline & $\mathrm{X} 13$ & 26.75 & 28.95 & 18.86 & 25.44 & 3.74 & $\mathrm{HV}$ \\
\hline & X14 & 17.98 & 27.63 & 25.00 & 29.39 & 3.77 & $\mathrm{P}$ \\
\hline Average & & & & & & 3.69 & \\
\hline \multirow{6}{*}{ 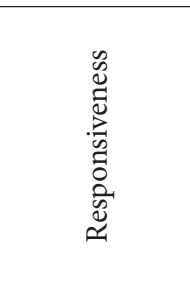 } & $\mathrm{X} 15$ & 23.68 & 26.75 & 29.39 & 20.18 & 3.57 & $\mathrm{~N}$ \\
\hline & $\mathrm{X} 16$ & 22.81 & 23.25 & 26.75 & 27.19 & 3.34 & $\mathrm{CF}$ \\
\hline & $\mathrm{X} 17$ & 24.56 & 21.49 & 26.75 & 27.19 & 3.52 & $\mathrm{CF}$ \\
\hline & $\mathrm{X} 18$ & 21.49 & 23.68 & 27.19 & 27.63 & 3.29 & CF \\
\hline & X19 & 23.68 & 21.49 & 29.39 & 25.44 & 3.35 & $\mathrm{~N}$ \\
\hline & $\mathrm{X} 20$ & 27.63 & 29.82 & 18.86 & 23.68 & 3.95 & $\mathrm{HV}$ \\
\hline Average & & & & & & 3.50 & \\
\hline \multirow{6}{*}{ 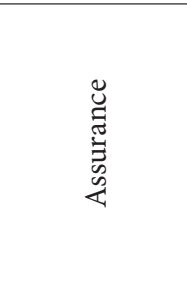 } & $\mathrm{X} 21$ & 26.32 & 28.95 & 22.37 & 22.37 & 3.56 & LV \\
\hline & $\mathrm{X} 22$ & 23.68 & 22.81 & 26.32 & 27.19 & 3.55 & $\mathrm{CF}$ \\
\hline & $\mathrm{X} 23$ & 26.32 & 29.82 & 27.19 & 16.67 & 4.02 & $\mathrm{HV}$ \\
\hline & $\mathrm{X} 24$ & 28.51 & 26.75 & 24.12 & 20.61 & 3.72 & HA \\
\hline & $\mathrm{X} 25$ & 25.88 & 32.89 & 22.81 & 18.42 & 4.08 & $\mathrm{HV}$ \\
\hline & $\mathrm{X} 26$ & 25.88 & 31.58 & 21.93 & 20.61 & 4.07 & $\mathrm{HV}$ \\
\hline Average & & & & & & 3.83 & \\
\hline \multirow{6}{*}{ 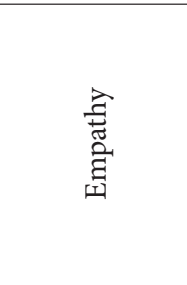 } & $\mathrm{X} 27$ & 27.19 & 26.75 & 25.00 & 21.05 & 4.04 & $\mathrm{HA}$ \\
\hline & $\mathrm{X} 28$ & 27.63 & 23.68 & 25.00 & 23.68 & 3.78 & HA \\
\hline & $\mathrm{X} 29$ & 22.37 & 25.88 & 27.63 & 24.12 & 3.57 & $\mathrm{~N}$ \\
\hline & $\mathrm{X} 30$ & 19.30 & 28.07 & 29.39 & 23.25 & 3.95 & $\mathrm{C}$ \\
\hline & $\mathrm{X} 31$ & 21.93 & 19.74 & 28.51 & 29.82 & 3.58 & $\mathrm{CF}$ \\
\hline & $\mathrm{X} 32$ & 27.19 & 21.93 & 25.88 & 25.00 & 3.70 & $\mathrm{HA}$ \\
\hline Average & & & & & & 3.77 & \\
\hline Total Average & & & & & & 3.69 & \\
\hline
\end{tabular}

to perform a more precise service quality analysis (Yang, 2005). The Refined Kano model puts "Attractive" further into Highly attractive (HA) \& Less attractive (LA); "Must be" (M) into Critical (C) \& Necessary (N); "One-dimensional" (O) into High value-added (HV) \& Low valueadded (LV); "Indifferent" (I) into Potential (P) \& Care-free (CF). Refined Kano Quality Attributes (Table 5) shows that the five facets are ranked, according to their importance, as following: Assurance, Empathy, Reliability, Tangibles, and Responsiveness. In the Refined Kano model analysis
(See Table 3; Table 5), HA includes: "X3, X24, X27, X28, X32"; LA: Only "X4"; C: "X9, X12, X30"; N: "X8, X15, X19, X29"; HV: "X1, X2, X7, X10, X13, X20, X23, X25, $\mathrm{X} 26$ "; LV: only "X21"; P: only "X14"; CF: "X5, X6, X11, $\mathrm{X} 16, \mathrm{X} 17, \mathrm{X} 18, \mathrm{X} 22, \mathrm{X} 31$," hence 32 items in total.

\subsection{Customer satisfaction matrix}

The research adopted the customer satisfaction matrix in which the SC falls at the center of the X axis and DSC at the center of the $\mathrm{Y}$ axis, with the absolute value of the 


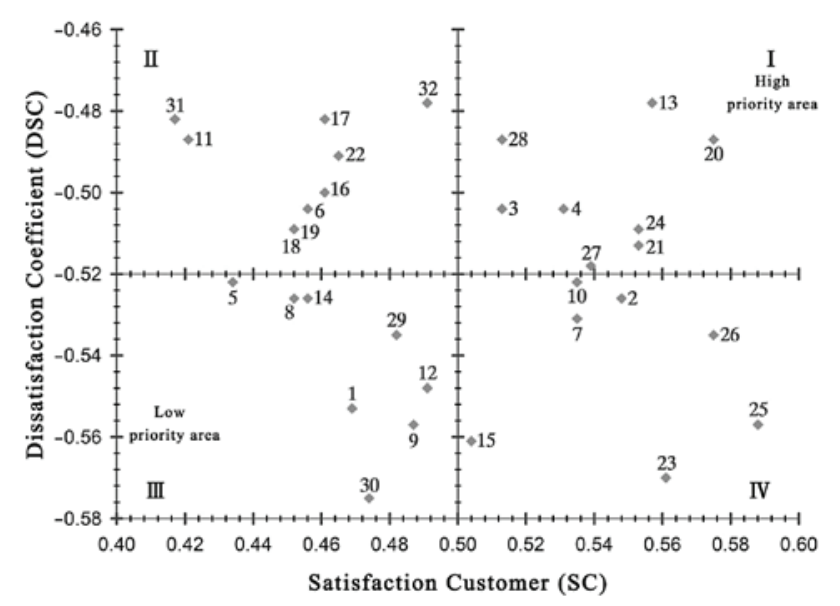

Figure 2. Kano model quality attributes analysis

correlation coefficient ranged from 0 to 1 . When the coefficient is closer to 1 , it indicates that the quality of the service quality attributes has been visibly improved, and this will have an impact on customer satisfaction.

The result of the survey is reflected in (Figure 2), "X3, X4, X13, X20, X21, X24, X27, X28" which falls into the first quadrant are the key service quality attributes of property services, and 8 of the key service quality attributes enter in either the "Attractiveness" (A) category or the "One-dimensional" (O) category. After all, if the decision maker is determined to take a more ambitious approach, he should focus working on the 8 quality attributes which fall into the 1st quadrant; if the decision maker decides to work on the 7 quality attributes in the 4th quadrant, this will significantly bring up customer satisfaction. On the other hand, if the decision maker tends to be less ambitious, then he or she may consider making appropriate adjustments to the 9 quality attributes within the 2nd quadrant, which will not increase customer satisfaction but rather offset the dissatisfaction. Nevertheless, the 8 quality attributes within the 3rd quadrant may be suspended. Thus, the property services provider, under conditions where resources are sufficient, may considering adjust and reinforce its scope of services according to the needs of different type of residential communities. Therefore, the property service items studied in the present research are of two-dimensional quality attributes.

\section{Discussion}

Understanding the needs and expectations of customers is a key factor for the success of an enterprise, which includes all types of commercial organizations. High customer satisfaction will enhance customer loyalty and create a sustainable competitive advantage in a saturated market (Balkyte \& Tvaronavičiene, 2010; Matzler \& Hinterhuber, 1998; S. P. Saeidi, Sofian, P. Saeidi, S. P. Saeidi, \& S. A. Saaeidi, 2015; Vilanova, Lozano, \& Arenas, 2009). Many scholars (Dominici \& Palumbo, 2013; Luor et al., 2015; Witell et al., 2013) consider that the Kano model has many merits.
When this model is employed, it helps to clearly describe the quality factors that meet the customers' needs. Therefore, from the foregoing data analysis and research questions, which are further discussed in detail.

\subsection{Degree of importance of the five defined facets}

Among the five facets defined by the present research, Assurance is the most valued by customers. Through the interview results, the nature of property service related works seem to be considered as labour-extensive work, such as: security guardian, janitorial services, etc. However, along with the evolution of society, people have become more inclined to humanitarian issues, emphasizing professionalism and meticulous provision of services. These features have become the key reasons for transforming property management services in companies. Secondly, the top-three services items of which customers make most account are: X25, X26, X23, suggesting that they highly appreciate clear prior-instructions, security and maintenance of the residential community, and improvements in financial management. The responsiveness facet contained six quality attributes, reflecting the immediateness of services provided. We found via the interviews that lack in relevant knowledge and skills due to insufficient training or inaptitude of personnel may occur when employees carry out certain services, which make them unable to respond to and communicate well with the clients. Hence, we suggested that the service provider should adopt a more proactive approach so that its customers feel that they are being served with greater respect.

\subsection{Refined Kano model summary}

From the above information, one-fourth of the property services criterion suggested by the present research fall into the "Indifferent" (I) category, out of which one is subcategorized into the "Potential" $(\mathrm{P})$ category, and the rest eight items are found within "Care-free" (CF) category, thus a total of nine items. This outcome indicates that there is an apparent gap between service quality provided and customer perception, where the needs of the latter are not satisfied by existing offers of the former. Regarding the eight service quality attributes within the "Care-free" (CF) category, it is recommended that property services providers shall carry out a survey according to the positioning of the residential community, accounting records of community operation and management fees, and the age of the buildings, etc. in order to make necessary adjustments of its current service scope. If the property services provider has concerns on the operating expenses, it might wish to avoid over spend efforts and resources. Especially, if the Turnover of service staff is lowered, it will help to reduce expenditures on frequent staff training \& education, and allow the service provider to maintain its competiveness. We have found out that many property services providers had indeed established internal training center to cater training programs on property management practices, crisis management, skills to cope with unexpected incidents, 
computer skills, etc. to sharpen professional know-how of employees in order to satisfy customers' needs. Furthermore, experts point out that if companies could reasonably increase wages of their service personnel, or provide incentives to those who have shown more seniority and / or outstanding work performance, for this will improve human capital loss due to low wages. Secondly, during the discussions with service providers interviewed, we observed that the problem of low wages is a key factor causing high staff turnover. Moreover, as a result of limited budgets, companies often employ insufficient manpower, requiring employees to work overtime constantly. If a residential community regularly alter its property management agency or has very high staff turnover, it will not be able to provide the services expected and appreciated by residents.

\subsection{Service differentiation strategy}

We can see from Table 5 that the five quality attributes of "X3, X24, X27, X28, X32" fall into the "Highly Attractive" (HA) category, indicating that they are the key means to for property services providers to attract more clients. Hence, companies should work on enhancing more quality attributes from this category.

Besides, the quality attributes of "X4" enter the "Less Attractive" (LA) category, which will not significantly impact attracting customers, and property services providers can evaluate whether they should work on increasing this type of quality attributes or not. Secondly, the attributes "X18, X8, X16" are the top three to be improved, jointly with expectancy theory and Parasuraman et al. (1988), allow us to further study the communication gap found within property services. Therefore, we suggest that property services providers to take the following measures:

- Attributes of X16 and X18 fall into the "Care-fee"

(CF) category, implying that value- added services are often not catered to by small-sized property services providers. Thus, the operator may carry out research according to the residential community's positioning, the income and expenditure related to the residential management, the building's age, etc. Proximately, the property services provider may inform the results to their residents and the residential management committee for evaluation and opinions. Besides, companies may also consider offering the free choice to certain residents. The measures will definitely be appreciated and valued by residents and the committee if fully implemented.

- The quality attributes of "X8" fall into the "Necessary" (N) category. First, the property services provider should see and make attempts to settle with the committee about services which do not meet the expectations of the latter, in order to fulfill its tasks and better meet the client's needs and expectations. Second, companies may also consider providing valuegraded services such as having a full-time secretary, or letting the committee hire its own service staff in order to improve service quality.

\section{Conclusions}

Property services providers must seek to identify the key factors that impact service qualities and define appropriate solutions accordingly. This integrated a new model framework to maximize service quality of the property services industry under budget constraints. It involves identification and classification of service quality element as well as quantitative analysis of the formulation of the decision model. The results show that a lower turnover rate of service staff (X14) shall be considered the quality attribute of Potential $(\mathrm{P})$, inferring that a lower dismissal rate of service staff allows the management to reduce oftincurred training expenditures and maintain the company's competitiveness. The main implications of this study are as follows: first, drawing upon the relevant literature on property management, this study creates a powerful new service model, which confirms the hypothesis that the service quality elements of property management correspond to different quality attributes. This model is developed to acquire accurate and critical service attributes, the priority rankings of which can promote customer satisfaction. In terms of theoretical implications, the model sought to fill the existing gaps in the property management literature by providing a framework for the study of property management dynamics. This study is the first work of research to successfully apply an integrated model with different quality attributes in the property management sector. Second, in terms of managerial implications, property services providers must seek to identify the key factors that affect service quality and to define appropriate solutions therefrom. The empirical findings may be useful to property services providers by their provision of vital information about the key factors influencing service quality. This promises to help the property management industry propose improvements for better efficiency and create value in the service policies of its constituent firms. Academically, this study has certain limitations that should be addressed in future research since the targets of the property management industry (shopping centers, hospitals, and luxury housing) and its service projects differ from those of other industries in terms of features and characteristics. Some of the aspects of property management services might not be applicable to these businesses. Therefore, it is necessary to make adjustments to the services based on the empirical studies differences and the type of business. Lastly, more decision method used in should be conducted to test the model's applicability.

\section{Recommendations}

Property services providers may increase profitability through use of property innovation and value creating service quality questionnaire to achieve the win-win goal for themselves and their customers. Although each housing community is unique, they may face similar problems, which is why the lessons learned from studying the property management market may be applied. We suggest com- 
panies to collaborate with research institutions to find out means of improving human resource management, and eventually stabilize service staff turnover. The focus of further research will be on whether these aspects of property services can continuously be updated. Lastly, we may foresee the operation of property management to become more standardized and electronized with more professional and humane approach. It is recommended to expand the survey to other geographical zones in order to better understand opinions of residents from different locations.

\section{Acknowledgements}

The authors greatly thank two anonymous referees for giving their constructive comments on improving the quality of this paper.

\section{References}

Anderson, E. W., \& Mittal, V. (2000). Strengthening the satisfaction-profit chain. Journal of Service Research, 3(2), 107-120. https://doi.org/10.1177/109467050032001

Balkyte, A., \& Tvaronavičiene, M. (2010). Perception of competitiveness in the context of sustainable development: facets of "sustainable competitiveness". Journal of Business Economics and Management, 11(2), 341-365. https://doi.org/10.3846/jbem.2010.17

Baruch, Y., \& Holtom, B. C. (2008). Survey response rate levels and trends in organizational research. Human Relations, 61(8), 1139-1160. https://doi.org/10.1177/0018726708094863

Basfirinci, C., \& Mitra, A. (2015). A cross cultural investigation of airlines service quality through integration of Servqual and the Kano model. Journal of Air Transport Management, 42, 239-248. https://doi.org/10.1016/j.jairtraman.2014.11.005

Borgianni, Y., \& Rotini, F. (2015). Towards the fine-tuning of a predictive Kano model for supporting product and service design. Total Quality Management \& Business Excellence, 26(3-4), 263-283. https://doi.org/10.1080/14783363.2013.791119

Chen, L. F. (2012). A novel approach to regression analysis for the classification of quality attributes in the Kano model: an empirical test in the food and beverage industry. Omega, 40(5), 651-659. https://doi.org/10.1016/j.omega.2011.12.004

Chen, W. T., Huang, Y. H., \& Chen, J. W. (2016). Using factor analysis to extract the critical success factors of property management for residential housing. Journal of Property Management, 7(2), 1-16.

Chiang, T. Y., Perng, Y. H., \& Liou, L. E. (2017). Impact and adaptation strategies in response to climate change on Taiwan's water resources. Applied Mechanics \& Materials, 858, 335-341. https://doi.org/10.4028/www.scientific.net/AMM.858.335

Dabholkar, P. A., Thorpe, D. I., \& Rentz, J. O. (1996). A measure of service quality for retail stores: scale development and validation. Journal of the Academy of Marketing Science, 24(1), 3-16. https://doi.org/10.1007/BF02893933

Das, A., Kumar, V., \& Saha, G. C. (2010). Retail service quality in context of CIS countries. International Journal of Quality \& Reliability Management, 27(6), 658-683. https://doi.org/10.1108/02656711011054542

Dočekalová, M. P., \& Kocmanová, A. (2016). Composite indicator for measuring corporate sustainability. Ecological Indicators, 61, 612-623. https://doi.org/10.1016/j.ecolind.2015.10.012

Dominici, G., \& Palumbo, F. (2013). The drivers of customer satisfaction in the hospitality industry: applying the Kano model to Sicilian hotels. International Journal of Leisure and Tourism Marketing, 3(3), 215-236.

https://doi.org/10.1504/IJLTM.2013.052623

Ferreira, F. A., Spahr, R. W., Sunderman, M. A., Banaitis, A., \& Ferreira, J. J. (2017). A learning-oriented decision-making process for real estate brokerage service evaluation. Service Business, 11(3), 453-474. https://doi.org/10.1007/s11628-016-0315-4

Griswold, R. S. (2013). Property management kit for dummies. New York, NY: John Wiley \& Sons.

Hair, J. F., Black, W. C., Babin, B. J., Anderson, R. E., \& Tatham, R. L. (2009). Analise Multivariada de Dados. Porto Alegre, PA: Bookman.

Herzberg, F., Mausner, B., \& Snyderman, B. B. (1959). The motivation to work. New York, NY: John Wiley \& Sons.

Hopkins, E. A., Read, D. C., \& Goss, R. C. (2017). Promoting sustainability in the United States multifamily property management industry. Journal of Housing and the Built Environment, 32(2), 361-376. https://doi.org/10.1007/s10901-016-9516-3

Hu, K. C., \& Hsiao, M. W. (2016). Quality risk assessment model for airline services concerning Taiwanese airlines. Journal of Air Transport Management, 53, 177-185. https://doi.org/10.1016/j.jairtraman.2016.03.006

Hurley, R. F., \& Estelami, H. (1998). Alternative indexes for monitoring customer perceptions of service quality: a comparative evaluation in a retail context. Journal of the Academy of Marketing Science, 26(3), 209-221.

https://doi.org/10.1177/0092070398263003

Kano, N., Seraku, N., Takahashi, F., \& Tsuji, S. (1984). Attractive quality and must-be quality. Journal of the Japanese Society for Quality Control, 14(2), 39-48.

Kim, J. M., \& Choi, S. B. (2017). An integrated application of Kano's model and AHP to Korean online open market services. Multimedia Tools and Applications, 76(19), 19621-19634. https://doi.org/10.1007/s11042-016-3323-4

Liu, C. W., Lin, K. H., \& Kuo, Y. M. (2003). Application of factor analysis in the assessment of groundwater quality in a blackfoot disease area in Taiwan. Science of The Total Environment, 313(1-3), 77-89. https://doi.org/10.1016/S00489697(02)00683-6

Lu, S. T., Shiu, J. Y., \& Chang, D. S. (2014). Development of management support system for property management enterprises. Open Journal of Social Sciences, 2, 127-132.

https://doi.org/10.4236/jss.2014.29022

Luor, T., Lu, H. P., Chien, K. M., \& Wu, T. C. (2015). Contribution to quality research: a literature review of Kano's model from 1998 to 2012. Total Quality Management \& Business Excellence, 26(3-4), 234-247. https://doi.org/10.1080/14783363.2012.733264

Marshall, M. N. (1996). Sampling for qualitative research. Family Practice, 13(6), 522-526. https://doi.org/10.1093/fampra/13.6.522

Matzler, K., \& Hinterhuber, H. H. (1998). How to make product development projects more successful by integrating Kano's model of customer satisfaction into quality function deployment. Technovation, 18(1), 25-38. https://doi.org/10.1016/S0166-4972(97)00072-2

Mikulić, J., \& Prebežac, D. (2011). A critical review of techniques for classifying quality attributes in the Kano model. Managing Service Quality: An International Journal, 21(1), 46-66. https://doi.org/10.1108/09604521111100243

Mishra, D., Akman, I., \& Mishra, A. (2014). Theory of reasoned action application for green information technology acceptance. Computers in Human Behavior, 36, 29-40. https://doi.org/10.1016/j.chb.2014.03.030 
Nadiri, H., \& Hussain, K. (2005). Diagnosing the zone of tolerance for hotel services. Managing Service Quality: An International Journal, 15(3), 259-277. https://doi.org/10.1108/09604520510597818

Nunnally, J. C. (1978). Psychometric theory. New York, NY: McGraw-Hill.

Oh, H., \& Kim, K. (2017). Customer satisfaction, service quality, and customer value: years 2000-2015. International Journal of Contemporary Hospitality Management, 29(1), 2-29. https://doi.org/10.1108/IJCHM-10-2015-0594

Ooi, K. B., Lin, B., Tan, B. I., \& Chong, A. Y. L. (2011). Are TQM practices supporting customer satisfaction and service quality?. Journal of Services Marketing, 25(6), 410-419. https://doi.org/10.1108/08876041111161005

Parasuraman, A., Zeithaml, V. A., \& Berry, L. L. (1985). A conceptual model of service quality and its implications for future research. Journal of Marketing, 49(4), 41-50. https://doi.org/10.2307/1251430

Parasuraman, A., Zeithaml, V. A., \& Berry, L. L. (1988). SERVQUAL: a multiple-item scale for measuring consumer perceptions of service quality. Journal of Retailing, 64(1), 12-37.

Park, Y., El Sawy, O. A., \& Fiss, P. C. (2017). The role of business intelligence and communication technologies in organizational agility: a configurational approach. Journal of the Association for Information Systems, 18(9), 648-686. https://doi.org/10.17705/1jais.00001

Read, D. C., Goss, R. C., \& Hopkins, E. (2017). Strategic business development and client prospecting in the third-party apartment management industry. International Journal of Strategic Property Management, 21(4), 346-356. https://doi.org/10.3846/1648715X.2017.1317297

Rubin, H. J., \& Rubin, I. S. (2011). Qualitative interviewing: the art of hearing data. Thousand Oaks, CA: Sage.

Saeidi, S. P., Sofian, S., Saeidi, P., Saeidi, S. P., \& Saaeidi, S. A. (2015). How does corporate social responsibility contribute to firm financial performance? The mediating role of competitive advantage, reputation, and customer satisfaction. Journal of Business Research, 68(2), 341-350. https://doi.org/10.1016/j.jbusres.2014.06.024

Shahin, A., Pourhamidi, M., Antony, J., \& Hyun Park, S. (2013). Typology of Kano models: a critical review of literature and proposition of a revised model. International Journal of Quality \& Reliability Management, 30(3), 341-358.

https://doi.org/10.1108/02656711311299863

Terwee, C. B., Bot, S. D. M., de Boer, M. R., van der Windt, D. A. W. M., Knol, D. L., Dekker, J., Bouter, L. M., de Vet, H. C. W. (2007). Quality criteria were proposed for measurement properties of health status questionnaires. Journal of Clinical Epidemiology, 60, 34-42. https://doi.org/10.1016/j.jclinepi.2006.03.012
Tontini, G., Søilen, K. S., \& Silveira, A. (2013). How do interactions of Kano model attributes affect customer satisfaction? An analysis based on psychological foundations. Total Quality Management \& Business Excellence, 24(11), 1253-1271. https://doi.org/10.1080/14783363.2013.836790

Vilanova, M., Lozano, J. M., \& Arenas, D. (2009). Exploring the nature of the relationship between CSR and competitiveness. Journal of Business Ethics, 87(1), 57-69. https://doi.org/10.1007/s10551-008-9812-2

Van Iwaarden, J., van der Wiele, T., Ball, L., \& Millen, R. (2003). Applying SERVQUAL to Web sites: an exploratory study. International Journal of Quality \& Reliability Management, 20(8), 919-935. https://doi.org/10.1108/02656710310493634

Wang, H., Kim, K. H., Ko, E., \& Liu, H. (2016). Relationship between service quality and customer equity in traditional markets. Journal of Business Research, 69(9), 3827-3834. https://doi.org/10.1016/j.jbusres.2016.04.007

Wang, T., \& Ji, P. (2010). Understanding customer needs through quantitative analysis of Kano's model. International Journal of Quality \& Reliability Management, 27(2), 173-184. https://doi.org/10.1108/02656711011014294

Wang, Y. L., Luor, T., Luarn, P., \& Lu, H. P. (2015). Contribution and trend to quality research - a literature review of SERVQUAL model from 1998 to 2013. Informatica Economica, 19(1), 34-45. https://doi.org/10.12948/issn14531305/19.1.2015.03

Watson, J. C. (2017). Establishing evidence for internal structure using exploratory factor analysis. Measurement and Evaluation in Counseling and Development, 50(4), 232-238. https://doi.org/10.1080/07481756.2017.1336931

Weiss, R. S. (1994). Learning from strangers: the art and method of qualitative interview studies. New York, NY: The Free Press.

Witell, L., Löfgren, M., \& Dahlgaard, J. J. (2013). Theory of attractive quality and the Kano methodology - the past, the present, and the future. Total Quality Management \& Business Excellence, 24(11-12), 1241-1252. https://doi.org/10.1080/14783363.2013.791117

Yang, C. C. (2005). The refined Kano's model and its applications. Total Quality Management \& Business Excellence, 16(10), 1127-1137. https://doi.org/10.1080/14783360500235850

Yang, C. C., Jou, Y. T., \& Cheng, L. Y. (2011). Using integrated quality assessment for hotel service quality. Quality \& Quantity, 45(2), 349-364. https://doi.org/10.1007/s11135-009-9301-4

Zhao, X., Bai, C., \& Hui, Y. V. (2002). An empirical assessment and application of SERVQUAL in a mainland Chinese department store. Total Quality Management, 13(2), 241-254. https://doi.org/10.1080/09544120120102478 